\title{
Efficacy and dosage of enalapril in congenital and acquired heart disease
}

\author{
Alison M Leversha, Nigel J Wilson, Patricia M Clarkson, A Louise Calder, \\ M Carol Ramage, John M Neutze
}

\begin{abstract}
In a tertiary referral centre 63 patients underwent 67 treatment periods with enalapril. The median age was 5.4 months. All children had signs of heart failure: congestive cardiac failure with breathlessness at rest was present in $88 \%$. Haemodynamic groups were left-to-right shunt $(n=15)$, impaired ventricular function $(n=14)$, after cardiac surgery $(n=23)$, valvar regurgitation $(n=12)$, and hypertension $(n=3)$. Serial clinical, radiological, and laboratory data were used to judge outcome.

The mean (SD) maximal dose was $0.30(0.21) \mathrm{mg} / \mathrm{kg} / \mathrm{day}$. Thirty nine $(58 \%)$ patients improved, $20(30 \%)$ showed no improvement, and eight $(12 \%)$ had side effects requiring discontinuation of enalapril. Renal failure in eight patients was related to young age, low weight, and left-to-right shunt group. Three patients died in congestive heart failure with renal failure.
\end{abstract}

Enalapril was clinically safe and effective for children with cardiac failure secondary to ventricular impairment, valvar regurgitation, or after cardiac surgery. Renal failure was a problem in young infants with left-to-right shunts.

(Arch Dis Child 1994; 70: 35-39)

Angiotensin converting enzyme (ACE) inhibitors are established for treatment in adults with congestive heart failure. They are known to provide significant haemodynamic, symptomatic, and clinical improvement when added to antifailure treatment. ${ }^{1-5}$ Two major recent prospective trials using enalapril have shown a reduction in mortality in mild, moderate, and severe congestive heart failure in adults. ${ }^{12} \mathrm{~A}$ proportion of patients, however, do not tolerate enalapril. 267

There is limited information on the use of

Cardiology

Department, Green

Lane Hospital, Epsom,

Auckland 1003, New

Zealand

Alison M Leversha

Nigel J Wilson

Patricia M Clarkson

A Louise Calder

M Carol Ramage

John M Neutze

Correspondence to:

Dr Wilson.

Accepted 3 September 1993 was to help establish the efficacy, appropriate dosage, safety, and tolerability of enalapril in a moderate sized paediatric population with heart disease of diverse aetiology. benefit from ACE inhibitors in children symptomatic left-to-right shunts or cardio-
Patients and methods

METHODS

From September 1986 to April 1991 enalapril was used in children with refractory heart failure where vasodilator treatment was considered potentially beneficial, unless surgery was imminent. Children received enalapril according to the following protocol: patients received a test dose of enalapril and, if this was tolerated, commenced regular treatment. Standard test doses were $0.1 \mathrm{mg}$ if less than 5 $\mathrm{kg}$ in weight, $0.2 \mathrm{mg}$ at $10 \mathrm{~kg}$, and $1.0-2.5 \mathrm{mg}$ for the larger child. Dosage was increased according to clinical response without a set upper dose limit. Blood pressure measurements were recorded before and 1-2 hours after initiation of enalapril and when dosage adjustments were made, allowing a small fall in blood pressure as an intended response. Details of all adjuvant treatment were noted as were subsequent changes.

To evaluate the efficacy of enalapril, the clinical assessment performed immediately before starting treatment was compared with serial assessments at approximately one week, at 1-3 months, and at the last medical consultation while on enalapril. All patients receiving enalapril were included in analysis even if they did not commence maintenance treatment. Signs of cardiac failure used during serial observation included measurements of weight, heart rate, respiratory rate, liver size, presence of gallop rhythm, and methods and volumes of feeding. Radiological data analysed were the cardiothoracic ratio, presence or absence of plethora, and pulmonary venous congestion. Serial echocardiographic left ventricular dimensions and left ventricular shortening fraction were used in assessment of those with impaired ventricular function. Serial measurements were made of serum sodium, urea, creatinine, and full blood count with differential. Serum potassium was not analysed as results were obtained from a mixture of venepuncture and capillary samples. An overall assessment of the efficacy of enalapril, judged primarily by changes in signs of congestive cardiac failure, was made from these data by two observers independent of the treating clinician; the patients were classified into one of three groups according to response: definite or probable clinical improvement due to enalapril; no changes; and discontinuation due to side effects. Renal failure was diagnosed when creatinine was $>0.08 \mathrm{mmol} / \mathrm{l}$ and/or urea was $>10 \mathrm{mmol} / 1$. Hypotension was categorised as a side effect when the blood pressure fall after enalapril was judged unacceptable and led to a reduction in dose. Changes in blood pressure 
Table 1 Dosage and clinical response to enalapril; mean (SD) dose of enalapril in $\mathrm{mg} / \mathrm{kg} / \mathrm{day}$

\begin{tabular}{|c|c|c|c|c|c|c|c|c|c|}
\hline \multirow[b]{2}{*}{ Category } & \multirow[b]{2}{*}{ Age range } & \multirow{2}{*}{\multicolumn{2}{|c|}{ No }} & \multicolumn{2}{|c|}{$\begin{array}{l}\text { Improved } \\
\text { enalapril }\end{array}$} & \multicolumn{2}{|c|}{$\begin{array}{l}\text { No change } \\
\text { enalapril }\end{array}$} & \multicolumn{2}{|c|}{$\begin{array}{l}\text { Side effects: } \\
\text { enalapril stopped }\end{array}$} \\
\hline & & & & No & & No & & No & \\
\hline $\begin{array}{l}\text { Left-to-right shunt } \\
\text { Impaired ventricular function } \\
\text { Valvar regurgitation } \\
\text { Postoperative palliation } \\
\text { Postoperative repair } \\
\text { Systemic hypertension } \\
\text { Pulmonary hypertension }\end{array}$ & $\begin{array}{l}9 \text { days }-9 \text { months } \\
3 \text { months }-17 \text { years } \\
4 \text { months- } 16 \text { years } \\
1 \text { month-6 years } \\
2 \text { months }-5 \text { years } \\
1 \text { year- } 4 \text { years } \\
13 \text { years }\end{array}$ & $\begin{array}{r}15 \\
14 \\
12 \\
16 \\
7 \\
2 \\
1\end{array}$ & & $\begin{array}{r}4 \\
8 \\
7 \\
12 \\
7 \\
1 \\
0\end{array}$ & $\begin{array}{l}0.19(0.16) \\
0.50(0.21) \\
0.27(0.20) \\
0.29(0.21) \\
0.41(0.25) \\
0.78\end{array}$ & $\begin{array}{l}6 \\
6 \\
4 \\
3 \\
0 \\
1 \\
0\end{array}$ & $\begin{array}{l}0.27(0.09) \\
0.24(0.12) \\
0.25(0.07) \\
0.18(0.05)\end{array}$ & $\begin{array}{l}5 \\
0 \\
1 \\
1 \\
0 \\
0 \\
1\end{array}$ & $\begin{array}{l}0 \cdot 11(0.04) \\
0 \\
0 \cdot 21 \\
0 \cdot 32\end{array}$ \\
\hline Total & & $\begin{array}{c}67 \\
100 \%\end{array}$ & $0.3(0.21)$ & $\begin{array}{l}39 \\
58 \%\end{array}$ & $0.36(0.24)^{\star}$ & $\begin{array}{l}20 \\
30 \%\end{array}$ & $\begin{array}{l}0 \cdot 24(0 \cdot 1) \\
12 \%\end{array}$ & 8 & $0.16(0.08)$ \\
\hline
\end{tabular}

$\star 2 p=0.04$ compared with dose of no change group.

Table 2 Patients with impaired ventricular function

\begin{tabular}{|c|c|c|c|c|c|c|c|}
\hline $\begin{array}{l}\text { Patient } \\
\text { No }\end{array}$ & Diagnosis & Age & $L V E D D$ & LVEDS & $\begin{array}{l}\text { LVSF } \\
\%\end{array}$ & $\begin{array}{l}\text { Time on } \\
\text { enalapril }\end{array}$ & Signs of congestive cardiac failure \\
\hline 1 & Dilated cardiomyopathy & 3 months & $\begin{array}{l}4 \cdot 6 \\
3 \cdot 5\end{array}$ & $\begin{array}{l}4 \cdot 3 \\
2 \cdot 8\end{array}$ & $\begin{array}{r}8 \\
20\end{array}$ & Baseline & \\
\hline 2 & Dilated cardiomyopathy & 5 months & $4 \cdot 7$ & $4 \cdot 3$ & 6 & $\begin{array}{l}5 \text { months } \\
\text { Baseline }\end{array}$ & Improved \\
\hline 3 & Dilated cardiomyopathy & 14 years & $\begin{array}{l}4 \cdot 0 \\
7 \cdot 0\end{array}$ & $\begin{array}{l}3 \cdot 3 \\
6 \cdot 2\end{array}$ & $\begin{array}{l}17 \\
12\end{array}$ & $\begin{array}{l}2 \text { months } \\
\text { Baseline }\end{array}$ & $\begin{array}{l}\text { Improved } \\
\text { Not improved }\end{array}$ \\
\hline 4 & Dilated cardiomyopathy & 17 years & $\begin{array}{l}7 \cdot 1 \\
7 \cdot 1\end{array}$ & $\begin{array}{l}6 \cdot 3 \\
6 \cdot 2\end{array}$ & $\begin{array}{l}12 \\
13\end{array}$ & Baseline & $\begin{array}{l}\text { Not improved } \\
\text { Not improved }\end{array}$ \\
\hline 5 & Myocarditis & 6 years & $\begin{array}{l}4 \cdot 7 \\
4 \cdot 6 \\
4 \cdot 4\end{array}$ & $\begin{array}{l}3 \cdot 7 \\
3 \cdot 6 \\
3 \cdot 2\end{array}$ & $\begin{array}{l}13 \\
22 \\
28\end{array}$ & $\begin{array}{l}\text { Baseline } \\
2 \text { months } \\
2 \cdot 3 \text { years }\end{array}$ & On immunosuppressives \\
\hline 6 & Myocarditis & 16 years & $6 \cdot 0$ & $4 \cdot \overline{5}$ & 25 & Baseline & Late improvement only \\
\hline 7 & Anthracycline cardiomyopathy & 5 years & $\begin{array}{l}6 \cdot 0 \\
4 \cdot 9 \\
5 \cdot 0 \\
4 \cdot 8\end{array}$ & $\begin{array}{l}4 \cdot 6 \\
4 \cdot 5 \\
3 \cdot 6 \\
4 \cdot 2\end{array}$ & $\begin{array}{r}30 \\
8 \\
28 \\
12\end{array}$ & $\begin{array}{l}2 \text { years } \\
\text { Baseline } \\
11 \text { months } \\
3 \text { years }\end{array}$ & $\begin{array}{l}\text { Improved } \\
\text { Early improvement } \\
\text { Late deterioration }\end{array}$ \\
\hline 8 & Anthracycline cardiomyopathy & 3 years & $\begin{array}{l}\text { Severe im } \\
\text { No chang }\end{array}$ & $\begin{array}{l}\text { npairment } \\
\text { ge LVSF }\end{array}$ & LVSF & $\begin{array}{l}\text { Baseline } \\
1 \text { month }\end{array}$ & Not improved \\
\hline 9 & $\begin{array}{l}5 \text { weeks postligation anomalous } \\
\text { left coronary artery }\end{array}$ & 5 months & Apical hy & pokinesia & & Baseline & $\begin{array}{l}\text { Apical hypokinesia improved at } \\
3 \text { months, late mild global } \\
\text { impairment }\end{array}$ \\
\hline 10 & $\begin{array}{l}7 \text { years postligation of right } \\
\text { coronary artery to right } \\
\text { ventricular fistula }\end{array}$ & 9 years & $\begin{array}{l}6 \cdot 3 \\
6 \cdot 5\end{array}$ & $\begin{array}{l}5 \cdot 2 \\
5 \cdot 3\end{array}$ & $\begin{array}{l}17 \\
18\end{array}$ & $\begin{array}{l}\text { Baseline } \\
20 \text { months }\end{array}$ & Improved \\
\hline 11 & $\begin{array}{l}\text { Past history rheumatic fever } \\
\text { and mitral and aortic valve } \\
\text { replacement }\end{array}$ & 15 years & $\begin{array}{l}5 \cdot 3 \\
5 \cdot 5\end{array}$ & $\begin{array}{l}3 \cdot 7 \\
3 \cdot 9\end{array}$ & $\begin{array}{l}\text { ' } 30 \\
\text { ' } 29\end{array}$ & $\begin{array}{l}\text { Baseline } \\
6 \text { months }\end{array}$ & Improved \\
\hline 12 & $\begin{array}{l}\text { Past history rheumatic fever and } \\
\text { aortic, mitral, and tricuspid } \\
\text { valve replacement }\end{array}$ & 14 years & $\begin{array}{l}7 \cdot 8 \\
7 \cdot 9\end{array}$ & $\begin{array}{l}7 \cdot 3 \\
7 \cdot 2\end{array}$ & $\begin{array}{l}7 \\
8\end{array}$ & $\begin{array}{l}\text { Baseline } \\
1 \text { month }\end{array}$ & Not improved \\
\hline 13 & $\begin{array}{l}\text { Past history rheumatic fever and } \\
\text { mitral valve replacement } \\
\text { Ectopic atrial tachycardia }\end{array}$ & 16 years & $\begin{array}{l}8 \cdot 4 \\
9 \cdot 6 \\
4 \cdot 4 \\
3 \cdot 2\end{array}$ & $\begin{array}{l}7 \cdot 9 \\
9 \cdot 1 \\
4 \cdot 0 \\
2 \cdot 2\end{array}$ & $\begin{array}{r}6 \\
6 \\
8 \\
31\end{array}$ & $\begin{array}{l}\text { Baseline } \\
7 \text { months } \\
\text { Baseline } \\
2 \text { weeks }\end{array}$ & $\begin{array}{l}\text { Not improved } \\
\text { Improved, also on antiarrhythmics }\end{array}$ \\
\hline
\end{tabular}

LVEDD = left ventricular end diastolic dimension $(\mathrm{cm}), \mathrm{LVESD}=$ left ventricular end systolic dimension $(\mathrm{cm}), \mathrm{LVSF}=$ left ventricular shortening fraction.

and renal function for the group were analysed by paired $t$ tests.

\section{PATIENTS}

Patients were subdivided into seven categories (table 1). Sixty seven treatment periods in 63 patients were included for analysis. Four patients received enalapril both preoperatively and postoperatively. No patients were excluded from analysis. The mean patient age at the start of enalapril treatment was 4.0 years, median 5.4 months (range 9 days-17.2 years). Weights ranged from $2.3 \mathrm{~kg}$ to $86.6 \mathrm{~kg}$. All patients had signs of heart failure, $88 \%$ showing congestion with breathlessness at rest. All patients were on other medication before starting enalapril, $91 \%$ receiving diuretics, $76 \%$ digoxin, and $72 \%$ both. Eight patients were changed from other vasodilators to enalapril (intravenous, oral, or transdermal patch preparations).

\section{Results}

DOSAGE AND OUTCOME

After a test dose, enalapril was increased in the first week to a mean dose of $0 \cdot 16 \mathrm{mg} / \mathrm{kg} /$ day (range $0.04-0.46 \mathrm{mg} / \mathrm{kg} /$ day) and subsequently to a mean maximal dose of $0.30 \mathrm{mg} / \mathrm{kg} /$ day (range 0.04 to $0.94 \mathrm{mg} / \mathrm{kg} /$ day). The lower range includes those in whom test doses only were given. Forty four patients received enalapril twice daily, 18 patients once daily, and five patients three times daily. The duration of treatment ranged from two doses only to over three years.

Overall, $58 \%$ of patients showed improvement in response to enalapril, 30\% showed no change in clinical condition, and $12 \%$ required discontinuation due to side effects (table 1). The dose received by those who improved was significantly greater $(2 p=0.04)$ than that received by those who showed no change (table 1). The left-to-right shunt category was the exception to the predominantly beneficial response; all but one patient in this group being less than 4 months of age. The echocardiographic changes in and course of patients with impaired ventricular function are detailed in table 2. Renal failure possibly contributed to early death in three infants with severe congestive heart failure (table 3 ). 
Table 3 Findings and outcome in patients who developed renal failure. Figures in parentheses refer to pretreatment values

\begin{tabular}{|c|c|c|c|c|c|c|c|c|c|c|}
\hline $\begin{array}{l}\text { Patient } \\
\text { No }\end{array}$ & ${ }^{t}$ Diagnosis & Age & $(m m o l l)$ & $\begin{array}{l}\text { Creatinine } \\
(\text { mmoll })\end{array}$ & $\begin{array}{l}\text { Urea } \\
\text { (mmoll) }\end{array}$ & $\begin{array}{l}\text { Sodium } \\
(\mathrm{mg} / \mathrm{kg} / \text { day })\end{array}$ & $\begin{array}{l}\text { Enalapril } \\
\text { (days) }\end{array}$ & $\begin{array}{l}\text { Duration } \\
\text { Renal outcome }\end{array}$ & Final result & Age \\
\hline $\begin{array}{l}1 \\
2 \\
2 \mathrm{~b} \\
3 \\
4 \\
5\end{array}$ & $\begin{array}{l}\text { CAVC, T21 } \\
\text { ASD, prematurity } \\
\text { VSD, ASD, PDA } \\
\text { Complex, PA band } \\
\text { Complex, PA band }\end{array}$ & $\begin{array}{l}4 \text { weeks } \\
8 \text { weeks } \\
11 \text { weeks } \\
9 \text { days } \\
5 \text { weeks } \\
6 \text { weeks }\end{array}$ & $\begin{array}{l}0.38(0.07) \\
0 \cdot 27(0.04) \\
0 \cdot 14(-) \\
0 \cdot 24(0.04) \\
0 \cdot 11(0.04) \\
0.09(0.03)\end{array}$ & $\begin{array}{l}28 \cdot 2(7 \cdot 5) \\
11 \cdot 3(6 \cdot 2) \\
12 \cdot 0(-) \\
20 \cdot 9(3 \cdot 0) \\
23 \cdot 4(7 \cdot 2) \\
10 \cdot 9(2 \cdot 7)\end{array}$ & $\begin{array}{l}118(121) \\
115(132) \\
132(135) \\
124(134) \\
123(133) \\
130(137)\end{array}$ & $\begin{array}{l}0 \cdot 09 \\
0 \cdot 16 \\
0 \cdot 16 \\
0 \cdot 05 \\
0 \cdot 32 \\
0 \cdot 19\end{array}$ & $\begin{array}{l}2 \\
3 \\
5 \\
2 \\
4 \\
5\end{array}$ & $\begin{array}{l}\text { Enalapril stopped } \\
\text { Enalapril stopped, recovered } \\
\text { Enalapril stopped, recovered } \\
\text { Enalapril stopped } \\
\text { Enalapril stopped } \\
\text { Enalapril continued, } \\
\text { recovered }\end{array}$ & $\begin{array}{l}\text { Died CCF/RF` } \\
\text { Died } \\
\text { Died CCF/RF` } \\
\text { Died CCF/RF` } \\
\text { Alive }\end{array}$ & $\begin{array}{l}4 \text { months } \\
13 \text { days } \\
5 \text { weeks } 5 \text { days } \\
3 \text { years }\end{array}$ \\
\hline 6 & VSD & 14 weeks & $0.06(0.03)$ & $15 \cdot 4(4 \cdot 3)$ & $126(133)$ & 0.09 & 5 & Enalapril stopped, recovered & $\begin{array}{l}\text { Alive } \\
\text { postoperatively }\end{array}$ & 4 years \\
\hline 7 & CAVC, T21 & 3 weeks & $0.06(-)$ & $14 \cdot 6(2 \cdot 6)$ & $123(141)$ & $0 \cdot 15$ & 14 & Enalapril stopped & $\begin{array}{l}\text { Died } \\
\text { postoperatively }\end{array}$ & 5 weeks \\
\hline $\begin{array}{l}8 \\
8 b\end{array}$ & CAVC, T21 & $\begin{array}{l}5 \text { weeks } \\
6 \text { weeks }\end{array}$ & $\begin{array}{l}0.05(0.04) \\
0 \cdot 10(0.04)\end{array}$ & $\begin{array}{l}12 \cdot 2(4 \cdot 5) \\
15 \cdot 8(7 \cdot 9)\end{array}$ & $\begin{array}{l}123(135) \\
122(126)\end{array}$ & $\begin{array}{l}0.06 \\
0.06\end{array}$ & $\begin{array}{l}4 \\
2\end{array}$ & $\begin{array}{l}\text { Enalapril stopped, recovered } \\
\text { Enalapril stopped, recovered }\end{array}$ & Died & 4 months \\
\hline
\end{tabular}

$\mathrm{ASD}=$ secundum atrial septal defect, $\mathrm{b}=$ repeat course of treatment, $\mathrm{CAVC}=$ complete $\mathrm{AV}$ canal, $\mathrm{CCF}=$ congestive cardiac failure, $\mathrm{PA}=$ pulmonary artery, $\mathrm{PDA}=$ patent ductus arteriosus, $\mathrm{RF}=$ renal failure, $T 21=$ trisomy $21, \mathrm{VSD}=$ ventricular septal defect.

^Enalapril related renal failure possibly contributed to death.

In the 14 patients with impaired left ventricular function, improvement (number of patients treated) was shown in two (four) with dilated cardiomyopathy, one (two) with myocarditis (one also receiving immunosuppressives), one (two) with anthracycline cardiomyopathy, one (one) postligation of anomalous left coronary artery, one (one) postligation of coronary to right ventricular fistula, one (one) with ectopic atrial tachycardia (also receiving antiarrhythmics), and one (three) postvalve surgery for rheumatic heart disease.

\section{BLOOD PRESSURE RESPONSE}

Enalapril caused a mean (SD) $3.4(7.9) \mathrm{mm} \mathrm{Hg}$ fall in systolic blood pressure 1-2 hours after the test dose and a $3 \cdot 1(5 \cdot 0) \mathrm{mm} \mathrm{Hg}$ fall after the maintenance doses (paired $t$ tests $\mathrm{p} \leqslant 0 \cdot 01$ ). Resting systolic and diastolic blood pressures on maintenance enalapril were lowered from baseline by $5.8(13.5) \mathrm{mm} \mathrm{Hg}$ and $5.6(12.2)$ $\mathrm{mm} \mathrm{Hg}$ respectively $(\mathrm{p} \leqslant 0.01)$.

\section{RENAL RESPONSE}

There were trends towards a fall in serum sodium concentration (mean (SD) 136 (5) to $133(6) \mathrm{mmol} / \mathrm{l}, \mathrm{p}=0.08$ ) and rise in serum creatinine $(0.04(0.02)$ to $0.06(0.05) \mathrm{mmol} / \mathrm{l}$, $\mathrm{p}=0.08)$ one week after starting enalapril.

\section{SIDE EFFECTS}

Side effects occurred in 19 of the $67(28 \%)$ treatment periods, eight $(12 \%)$ requiring discontinuation of enalapril. Hypotension occurred in nine patients and in one symptomatic patient enalapril was withdrawn. In the other eight asymptomatic patients enalapril was continued at a lower dose.

Renal failure occurred in eight patients, developing within five days of starting treatment in seven patients (table 3 ). There was an acute rise in serum creatinine in six patients and raised urea and oliguria in two. All were less than 4 months of age, had left-to-right shunts, and were receiving digoxin and diuretics. Serum sodium fell in all. Three patients (table 3, numbers 1, 3, and 4) died with intractable cardiac failure and renal failure within five days of commencement of enalapril. Variables related by univariate analysis ( $t$ tests or Fisher's exact test) to renal failure were young age, low weight, and the left-toright shunt haemodynamic category $(\mathrm{p}<0.01)$. There was a trend towards an association with pretreatment serum sodium $(p=0 \cdot 09)$ but all other variables assessed were unrelated: pretreatment serum urea and creatinine, starting and maintenance dose of enalapril, continued use of potassium sparing diuretics or potassium supplements, hypotension, and dehydration. Multivariate analysis was considered inappropriate with only eight patients with renal failure.

A cough that developed in one patient diminished after reduction of the enalapril dose. Neutropenia (minimum neutrophil count $=0.2 \times 10^{9} / 1$ ) occurred in one patient a week after commencing treatment but resolved promptly upon stopping enalapril.

\section{Discussion}

Studies using intravenous enalaprilat, the active metabolite of enalapril, have been helpful in establishing efficacy and dose of enalapril in children. A dose of $0.06 \mathrm{mg} / \mathrm{kg}$, approximately equivalent to $0 \cdot 12 \mathrm{mg} / \mathrm{kg}$ oral enalapril, was found to be safe and effective in children with left-to-right shunts. ${ }^{18}$ Mean aortic and pulmonary artery pressures decreased, the reduction in aortic pressures correlated with the plasma renin activity, and systemic flow was maintained. Pulmonary to systemic flow ratios decreased in those with a large ventricular septal defect and mild increase of pulmonary vascular resistance. Mean pulmonary vascular resistance decreased significantly in those in whom it was importantly increased, although there was considerable interindividual variation. Acute haemodynamic and hormonal changes have also been noted after $0.01-0.02 \mathrm{mg} / \mathrm{kg}$ intravenous enalaprilat. ${ }^{81518}$ A positive response to intravenous enalaprilat with reduction in pulmonary to systemic flow ratio was found to correlate with an increase in feeding and weight gain when infants were treated with a single daily dose of 0.16 $\mathrm{mg} / \mathrm{kg} .{ }^{15}$ The dosages of enalapril used in children with cardiac disease have varied, mean daily doses being $0.08-0.50 \mathrm{mg} / \mathrm{kg}$ ranging from $0.08-0.80 \mathrm{mg} / \mathrm{kg} /$ day. $^{11} 121415$ Frenneaux et al reported improvement in 
clinical features of heart failure in seven of eight infants treated with a mean daily dose of $0.26 \mathrm{mg} / \mathrm{kg}$. ${ }^{12}$ Lloyd et al found that the mean peak enalaprilat concentration four hours after $0.08 \mathrm{mg}$ of oral enalapril was $12.7 \mu \mathrm{g} / \mathrm{ml}$ and calculated a mean half life of $7 \cdot 6$ hours. ${ }^{11}$ They concluded that enalapril is less bioavailable, has a shorter duration of action in infants than in adults, and that a dose of $0.08 \mathrm{mg} / \mathrm{kg}$ daily was too small. A study of eight children with cardiomyopathy and heart failure showed that a single daily dose of $0.5 \mathrm{mg}$ resulted in diminished afterload without altering contractility. ${ }^{14}$ In the present study the dose received by those who improved was $0.36 \mathrm{mg} / \mathrm{kg} / \mathrm{day}$, significantly greater than the $0.24 \mathrm{mg} / \mathrm{kg} /$ day received by those who showed no improvement. This suggests that if tolerated enalapril should be increased to at least $0.36 \mathrm{mg} / \mathrm{kg} /$ day if no improvement in cardiac failure is observed at lower doses.

The relatively low incidence of clinical improvement and high incidence of renal failure observed in our infants with intracardiac shunts is in contrast with other retrospective studies of ACE inhibitor treatment. Frenneaux et al reported improvement in seven of eight infants treated with enalapril with a mean age of 1 month. Treatment was withdrawn in one because of hypotension, the infant later dying of intractable heart failure. ${ }^{12}$ Similarly, Shaw et al reported improvement in 19 of 20 infants treated with captopril, but two developed renal impairment. ${ }^{10}$ In another study six of seven infants with ventricular septal defects, median age 2.9 months, none of whom received diuretics, improved with enalapril. ${ }^{15}$ Our high incidence of renal failure in the left-to-right shunt group remains unexplained. It should be stressed that these were very ill infants with severe congestive heart failure. Young age was a dominant risk factor for renal failure, and neither dehydration nor concomitant use of potassium sparing diuretics appeared causative. It is recommended, however, that potassium sparing diuretics be discontinued when ACE inhibitors are started. ${ }^{19}$ Renal failure appears to be related to ACE inhibition rather than enalapril specifically. ${ }^{20}$ It has been suggested that timing of cardiac surgery in those with intracardiac shunts can be altered by the use of ACE inhibition, ${ }^{10} 12$ but only one such infant in the present study improved sufficiently for surgery to be deferred.

Eight of 14 patients with impaired ventricular function improved with enalapril, a worthwhile contribution in a group of diverse aetiology. Benefit is obviously limited in conditions with a poor natural history. Two studies of ACE inhibitors in children have reported a reduction in chamber size and volume without an improvement in contractility. ${ }^{914}$ More recently improvement in survival has been shown. ${ }^{17}$

Seven of the patients in the valvar regurgitation group had acute rheumatic fever with heart failure, five improving with enalapril. ACE inhibition allows smaller doses of diuretics to be used in such patients. Prospective studies will be needed to determine whether ACE inhibitors will preserve ventricular function in those with significant chronic valvar regurgitation.

The contribution of enalapril in postoperative patients with congestive cardiac failure is difficult to assess because of the expected improvement with time. Nevertheless, it is our firm impression that failure in the absence of major residual surgically correctable lesions can be improved by vasodilation in the recovery phase as well as in the immediate postoperative phase.

Of note is the occurrence of neutropenia in one patient upon initiation of treatment with enalapril. Although this is a relatively common side effect with captopril $(7 \cdot 2 \%),{ }^{21}$ its occurrence secondary to enalapril in adults is debated, ${ }^{22}$ and it has not been reported previously in children. This side effect is thought to be due to the presence of the sulphidryl group in captopril, but its occurrence with enalapril raises the possibility of an alternative mechanism. The occurrence of cough is a well documented symptom in association with the use of ACE inhibitors in adults ${ }^{2324}$ and has been reported in children. ${ }^{25}$

\section{CONCLUSION}

For patients with ventricular impairment, valvar regurgitation or refractory congestive heart failure after surgery, enalapril was judged effective in $69 \%$ and caused symptomatic side effects in only $4 \%$. Its use in patients with left-to-right shunts, largely restricted to small infants, was effective in only $27 \%$. Special care is required in this group because of the risk of renal impairment that was not dose related but confined to patients under four months of age.

The overall findings are comparable with studies in adults. Although a controlled trial in infants and children would be desirable, a useful role is confirmed.

We gratefully acknowledge the financial support of the National Heart Foundation of New Zealand to Dr Wilson, funded as a senior fellow.

1 The CONSENSUS trial study group. Effects of enalapril on mortality in severe congestive heart failure: results of the co-operative north Scandinavian enalapril survival stud (CONSENSUS). N Engl f Med 1987; 316: 1429-35.

2 The SOLVD investigators. Effect of enalapril on survival in patients with reduced left ventricular ejection fraction and congestive heart failure. $N$ Engl f Med 1991; 325: 293-302.

3 Cohn JN, Johnson G, Ziesche S. A comparison of enalapril with hydralazine-isosorbide dinitrate in the treatment of chronic congestive heart failure. $N$ Engl f Med 1991; 325: 303-10.

4 Sharpe DN, Murphy J, Coxon R, Hannan SF. Enalapril in patients with chronic heart failure: a placebo-controlled, patients with chronic heart failure: a placebo-controlled, 271-8.

5 Cleland JGF, Dargie HJ, Ball SG. Effects of enalapril in heart failure: a double blind study of effects on exercise performance, renal function, hormones, and metabolic state. Br Heart f 1985; 54: 305-12.

$6 \mathrm{Kjekshus} \mathrm{J,} \mathrm{Swedberg} \mathrm{K,} \mathrm{for} \mathrm{the} \mathrm{CONSENSUS} \mathrm{trial} \mathrm{study}$ group. Tolerability of enalapril in congestive heart failure. Am $\mathcal{f}$ Cardiol 1988; 62: 67A-72A.

7 Davies RO, Irvin JD, Kramsch DK, Walker JF, Moncloa F Enalapril worldwide experience. Am $\mathcal{f}$ Med 1984; 77 23-35.

8 Rheuban KS, Carpenter MA, Ayers CA, Gutgesell HP. Acute hemodynamic effects of converting enzyme inhibition in infants with congestive heart failure. $f$ Pediat 1990; 117: 668-70.

9 Stern H, Weil J, Genz T, Vogt W, Bühlmeyer K. Captopril in children with dilated cardiomyopathy: acute and longterm effects in a prospective study of hemodynamic and hormonal effects. Pediatr Cardiol 1990; 11: 22-8. 
10 Shaw NJ, Wilson N, Dickinson DF. Captopril in heart failure secondary to a left to right shunt. Arch Dis Child failure secondary

11 Lloyd TR, Mahoney LT, Knoedel D, Marvin WJ Jr, Robillard JE, Lauer RM. Orally administered enalapril for infants with congestive heart failure: a dose-finding study. f Pediatr 1989; 114: 650-4.

12 Frenneaux $M$, Stewart RAH, Newman $\mathrm{CMH}$, HallidieSmith KA. Enalapril for severe heart failure in infancy. Arch Dis Child 1989; 64: 219-23.

13 Boucek MM, Chang RL. Effects of captopril on the distribution of left ventricular output with ventricular septal ution of left ventricular output with
defect. Pediatr Res 1988; 24: 499-503.

14 Eronen M, Pesonen E, Wallgren EI, Tikkanen I, Fyhrquist F, Andersson S. Enalapril in children with congestive heart failure. Acta Paediatr Scand 1991; 80: 555-8.

15 Sluysmans T, Styns-Cailteux $M$, Tremouroux-Wattiez $M$, et al. Intravenous enalaprilat and oral enalapril in congestive heart failure secondary to ventricular septal defect in infancy. Am $\mathcal{F}$ Cardiol 1992; 70: 959-62.

16 Montigny M, Davignon A, Fouron J-C, Biron P, Fournier A, Elie R. Captopril in infants for congestive heart failure secondary to a large ventricular left-to-right shunt. $A m \mathcal{F}$ Cardiol 1989; 63: 631-3.

17 Lewis AB, Chabot $M$. The effect of treatment with angiotensin-converting enzyme inhibitors on survival of pediatric patients with dilated cardiomyopathy. Pediatr Cardiol 1993; 14: 9-12.

18 Webster MWI, Neutze JM, Calder AL. Acute hemodynamic effects of converting enzyme inhibition in children with intracardiac shunts. Pediatr Cardiol 1992; 13: 129-35.

19 Speirs CJ, Dollery CT, Inman WHW, Rawson NSB, Wilton LV. Postmarketing surveillance of enalapril. II: Investigation of the potential role of enalapril in deaths with renal failure. $B M F$ 1988; 297: 830-2.

20 Scammell AMN, Arnold R, Wilkinson JL. Captopril in treatment of infant heart failure: a preliminary report. Int f Cardiol 1987; 16: 295-301.

21 Frohlich ED, Cooper RA, Lewis EJ. Review of the overall experience of captopril in hypertension. Arch Intern Med experience of captop

22 Moncloa F, Sromovsky JA, Walker JF, Davies RO. Enalapril in hypertension and congestive heart failure: overall review of efficacy and safety. Drugs 1985; 30 (suppl 1): 82-9.

23 Rucinska EJ, Small R, Irvin J. High-risk patients treated with enalapril maleate: safety considerations. Int 7 Cardio 1989; 22: 249-59.

24 Coulter DM, Edwards IR. Cough associated with captopril and enalapril. $B M F$ 1987; 294: 1521-3.

25 Bianchetti MG, Caflisch M, Oetliker OH. Cough and converting enzyme inhibitors. Eur $\mathcal{f}$ Pediatr 1992; 151: converting $225-6$. 